\title{
Levels of some micronutrient in dried and fresh fruit samples of apricot cultivars
}

\author{
Davarynejad, D. G. ${ }^{1}$, Hamed, K. ${ }^{1}$, Nyéki J. ${ }^{2}$, Szabó Z. ${ }^{2}$ \& Nagy P. T. ${ }^{3}$ \\ ${ }^{1}$ Department of Horticultural Science, Ferdowsi University of Mashhad, Iran \\ ${ }^{2}$ Institute for Research and Development, University of Debrecen, Debrecen, Hungary \\ ${ }^{3}$ Institute of Environmental Sciences, Károly Róbert College, Gyöngyös, Hungary
}

\begin{abstract}
Summary: Concentration of Boron (B), Copper (Cu), Iron (Fe), Magnesium (Mg), Manganese (Mn) and Zinc (Zn) was analyzed in fresh and dried fruit samples of "Jumbo cot", "Tom cot", "Gold strike", "Gold bar", "Bergeron", "Bergrouge", "Sweet cot", "Yellow cot" and "Zebra" apricot cultivars. Concentration of the studied elements was strongly affected by cultivars. B, Cu, Fe, Mn and Zn content of "Tom cot" was significantly higher than other cultivars. "Gold strike" had the highest amount of Mg. Similar tendency was observed in "Zebra" and "Sweet

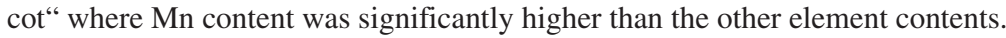

Key words: Prunus armeniaca, chemical composition, micronutrients

\section{Introduction}

Micro elements play an important role in the metabolic pathways during the growth and development of plants, when available in appreciable concentration. In addition to their essentiality for plant growth and/or human nutrition is also well known. Once in the soil, micro nutrients can accumulate in less soluble forms; they can enter the food chain, from soil and plant biota to human beings; or they can move to watersheds through leaching and erosion. Mineral fertilizers are a net source of trace metals and their long-term application can increase the total metal concentration in the soil and in the food chain as well (Nziguheba and Smolders, 2008). Plants reveal various tendencies in the uptake of trace elements. Three general uptake characteristics can be mentioned namely accumulation, indication and exclusion. To a large extent, this depends on the specific ability of plants and huge differences in metal uptake between plant species. Also, among the genotypes of a species, great variability had been demonstrated in many studies (Guo and Marschner, 1995; Dahmani-Muller et al., 2000). In general, the uptake of micro nutrients by plants, in addition to the plant-specific ability, is affected by soil factors, of which the most significant are $\mathrm{pH}, \mathrm{EC}$, water regime, clay content, organic matter content, cation exchange capacity, nutrient balance and the concentration of other trace elements. Besides, climatic conditions are shown to influence the rate of trace metal uptake, which may be partly an indirect impact due to the water flow phenomenon. Generally, a higher ambient temperature induces a greater uptake of trace elements by plants (Kabata-Pendias and Pendias, 2000).

Trace elements are intimately involved in the physiological function of all the human organs. They play a vital role in the regulation of cell functions, membrane functions etc. Alternatively, they may form parts of enzymes and serve as cofactors for enzyme-mediated reactions (Gowrishankar et al., 2010). It is well known that an excess or deficiency of trace metals present in the human body can cause harmful effects. For example an excess of $\mathrm{Cu}$ in the body cause Wilson's disease while a deficiency of $\mathrm{Zn}$ is responsible for retarded body growth (Zahir et al., 2009).

Fresh fruit consumption in human diet is continuously decreased nowadays. For example, about $15-20 \%$ of apricots produced are consumed fresh and the rest are processed as canned, dried, frozen, jam, juice and puree[10]. Several studies pointed out that eating dried fruit may be resulted extra benefits for human health according to the increasing amount of healthy contents like vitamins, essential elements and decreasing contents of fats. Different studies showed that $100 \mathrm{~g}$ of dried apricot contained $5 \mathrm{~g}$ of protein, $0.5 \mathrm{~g}$ fat, 66.5 $\mathrm{g}$ carbohydrate, $108 \mathrm{mg}$ phosphorus, $979 \mathrm{mg}$ potassium and $12 \mathrm{mg}$ vitamin $\mathrm{C}$ and they are rich in $\beta$-carotenes (Paunovic, 1985; Munzuroglu et al., 2003).

The aim of our study is to give further data about the concentration changing of some very important microelements in apricot cultivars regarding to drying procedure.

\section{Materials and methods}

Nine medium and late ripening apricot cultivars, all cultivated at the Boldogkőváralja commercial orchard of Hungary were used in this study. Fruits of "Jumbo cot", "Tom cot", "Gold strike", "Gold bar", "Bergeron", "Bergrouge", "Sweet cot", "Yellow cot" and "Zebra" were harvested at physiological maturity stages. The pits were 
removed from the fruits. Each cultivar divided into three groups containing about $300 \mathrm{~g}$ apricots respectively. The stoned and non sulphurated fruits were dried for 24 hours, using a household tray-dryer (Model Hauser).

Sample preparing was carried out in accordance to the relevant Hungarian standard (MSZ-08-1783-15:1985). Seeded, milled fruits without peeling were digested with concentrate $\mathrm{HNO}_{3}-\mathrm{H}_{2} \mathrm{O}_{2}$ digester mixture. Five grams of fresh fruit (two grams of dehydrated fruit) were digested at $120^{\circ} \mathrm{C}$ during three hours in a Teflon digester. Digested samples diluted with distilled water to $100 \mathrm{~cm}^{3}$. Examined elements were measured by Thermo Jarrell Ash Poly-scan 61E and Thermo Electron Corporation IRIS Intrepid II XDL Inductively coupled plasma emission spectrophotometer (ICP).

Data for the analytical determinations were subjected to analysis of variance (ANOVA). Mean comparisons were performed using Duncan multiple test to examine if differences were significant at $\mathrm{p}<0.05$.

\section{Results and discussion}

\section{Boron}

Boron is an essential element and primary found in fresh fruit such as pears, prunes, dates, grapes, raisins, nuts, green leafy vegetables and beans. Its role in human diet and health is widely published (Nielsen, 1997; Tagawa et al., 2000). Mean daily intakes of boron for male and female adults were reported to be 1.17 and $0.96 \mathrm{mg}$.
Concentration of Boron in fresh and dried apricot cultivars are given in Figl. To our knowledge, these data are the first to show that the Boron contents of dried apricot samples were found to be in the ranges of $16.57 \mathrm{mgkg}^{-1}$ in "Goldbar"cultivar to $40.09 \mathrm{mgkg}^{-1}$ in "Tom cot". Results for fresh samples exhibit a different range of metal concentration in cultivars with "Goldstrike" having the lowest amount (3.42 $\mathrm{mgkg}^{-1}$ ) and "Bergeron" indicating the highest concentration with $6.27 \mathrm{mgkg}^{-1}$.

There was no threatening dose of boron in any of the studied cultivars. On the other hand, these apricot cultivars could be a good source of boron for nutritional purposes.

\section{Copper}

$\mathrm{Cu}$ is an essential micronutrient and plays an important function as a cofactor for a number of cellular processes (Petris, 2004). Deficiency leads to anemia and bone marrow suppression, followed by a neurologic syndrome called a myelopathy (Hedera et al., 2003). In general, for most of us, diets containing 1-2 milligrams of copper, and not consuming large amounts of the copper antagonists vitamin C (>1000 milligrams) and zinc ( $>30$ milligrams) daily, a supplement of 1-3 milligrams of copper per day should be adequate. Total copper supplementation should not exceed 5 milligrams daily, except under a physician's supervision (Mansoor et al., 2000; Ford, 2000). Figure 2 shows that copper had the range of $0.67 \mathrm{mg} . \mathrm{kg}^{-1}$ in "Goldbar" to 1.28 $\mathrm{mg} \cdot \mathrm{kg}^{-1}$ in "Zebra" in fresh and $2.87 \mathrm{mg} \cdot \mathrm{kg}^{-1}$ in "Bergeron"

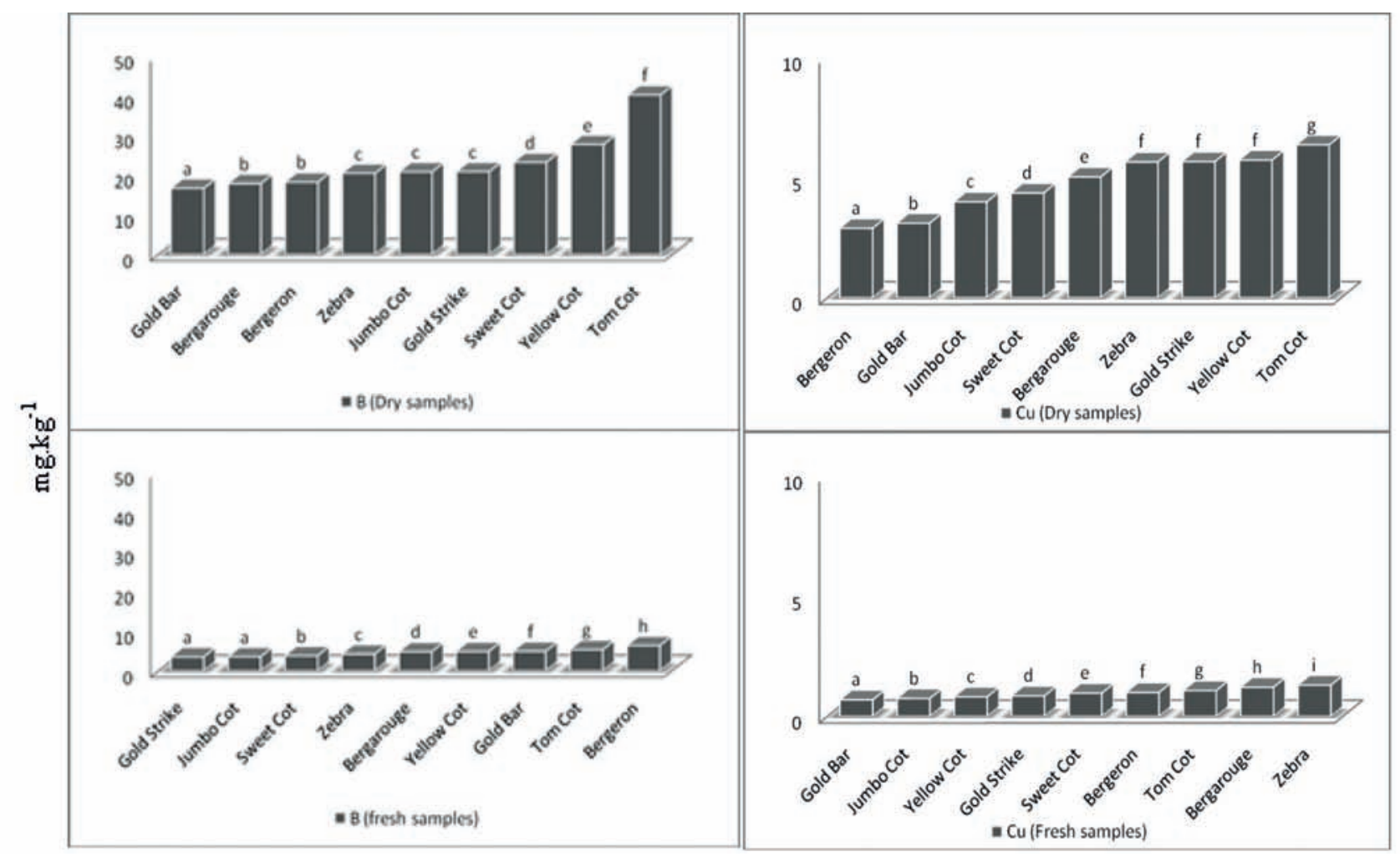

Figure 1. Concentration of Boron in apricot cultivars (mgkg-1), columns with different caption have a significant difference $(\mathrm{P} \leq 1 \%)$.

Figure 2. Concentration of Copper in apricot cultivars (mgkg-1), columns with different caption have a significant difference $(\mathrm{P} \leq 1 \%)$. 


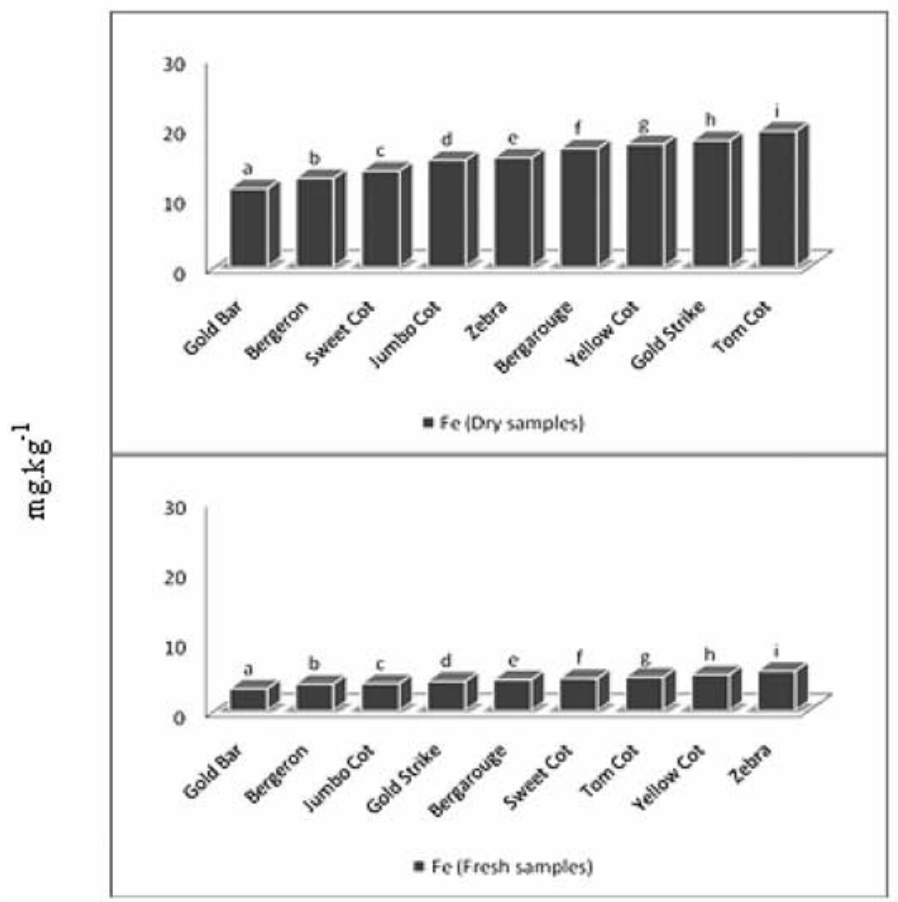

Figure 3. Concentration of Iron in apricot cultivars (mg.kg-1), columns with different caption have a significant difference $(\mathrm{P} \leq 1 \%)$.

to $6.34 \mathrm{mg} \cdot \mathrm{kg}^{-1}$ in "Tomcot" in dried samples. Average copper concentration of apricots in this study was higher than apricot samples of Turkey (Saracoglu et al., 2009) and Pakistan (Zahir et al., 2009) and was lower than health limits. This means that consumption of studied apricot cultivars could be beneficial to human health in the matter of copper. $\mathrm{Cu}$ concentration of fleshy tropical fruits of Colombia was reported in the range of $0.1 \mathrm{mg} / \mathrm{kg}$ in Ananas comosus to $8.1 \mathrm{mg} / \mathrm{kg}$ in Borojoa sorbilis (Leterme et al., 2006). Copper levels in vegetables have been reported in the range of 0.07-9.60 $\mathrm{mgkg}^{-1}$ (Onianwa et al., 2001; Bahemuka and Mubofu, 1999; Gebeloglu et al., 2004; Tüzen, 2003; Ferreira et al., 2005). These reports show that vegetables are a greater source of $\mathrm{Cu}$ in human diet whereas apricot can play an important role in the supplement of human need to $\mathrm{Cu}$ because of its potential to accumulate adequate concentrations of copper in its fruits.

\section{Iron}

Iron was in the range of $11.13-19.31 \mathrm{mgkg}^{-1}$ in "Gold bar" to "Tom cot" in dry samples. For fresh samples, "Goldbar" had the minimum and "Zebra" had the maximum concentration for Iron, $3.068 \mathrm{mgkg}^{-1}$ and $5.58 \mathrm{mgkg}^{-1}$ respectively (Fig. 3). Acute iron overload resulting from unintentional or intentional overdose is potentially life threatening. Iron deficiency anemia is the most prevalent cause of anemia affecting more than a half billion people worldwide [30] and it is also known that adequate iron in a diet is very important for decreasing the incidence of anemia. Recommended dietary allowances for Iron is about $18 \mathrm{mg}$.day ${ }^{-1}$ for women

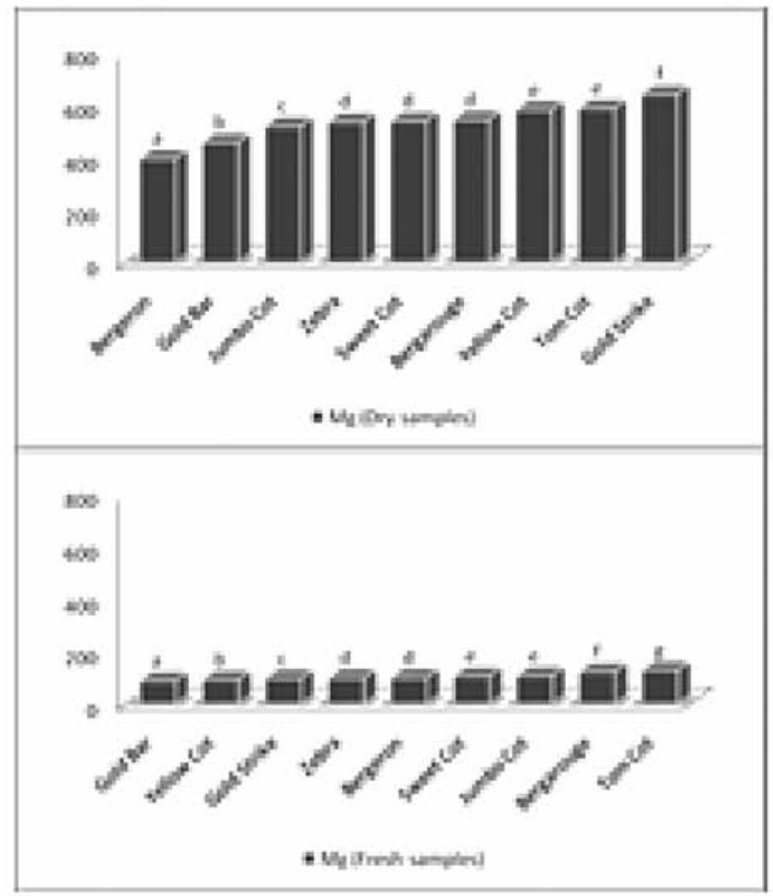

Figure 4. Concentration of Magnesium in apricot cultivars (mg.kg-1), columns with different caption have a significant difference $(\mathrm{P} \leq 1 \%)$.

and $8 \mathrm{mg}^{-d_{a y}}{ }^{-1}$ for men (Reilly, 2004). Saracoglu et al. (2009) reported that dried apricot samples in Turkey had a range of $10.4-80.1 \mathrm{mgkg}^{-1}$ of Fe which was higher than our results. Zahir et al. (2009) also counted the average $\mathrm{Fe}$ concentration of apricots about $14.086 \mathrm{mgkg}^{-1}$. These different concentrations of $\mathrm{Fe}$ in apricots from different regions may have occurred due to different orchard management methods, parent of soil and soil fertility or due to cultivars potential for Fe uptake. In comparison to mean value for concentration of Fe in black $\left(12.65 \mathrm{mgkg}^{-1}\right)$ and green $\left(7.8 \mathrm{mgkg}^{-1}\right)$ olives, it can be concluded that apricots have higher potential of Fe uptake and they should be placed in human diet.

\section{Magnesium}

$\mathrm{Mg}$ is required to redress and correct certain metabolic processes. Its ions are essential to all living cells, where they play a major role in manipulating important biological polyphosphate compounds like ATP, DNA, and RNA. Magnesium is a vital component of a healthy human diet. Suggested daily intake of $\mathrm{Mg}$ for adult males and females is about 270-400 mg and 280-300 mg respectively [32]. In our study, Magnesium concentration varies from $392.95 \mathrm{mg} \cdot \mathrm{kg}^{-1}$ in "Bergeron" to $638.63 \mathrm{mg} . \mathrm{kg}^{-1}$ in "Gold strike" in dried samples. In fresh samples "Goldbar" had the minimum concentration of Magnesium (85.77 mg.kg1) and "Tomcot" had the highest concentration of Magnesium (125.61 mg.kg-1) (Fig. 4). Nergiz and Engez (2000) and Yasar and Gucer (2004) reported that $\mathrm{Mg}$ concentrations in green olive were in the range of 114-372 and 132.0-223.3 $\mathrm{mgkg}^{-1}$, 


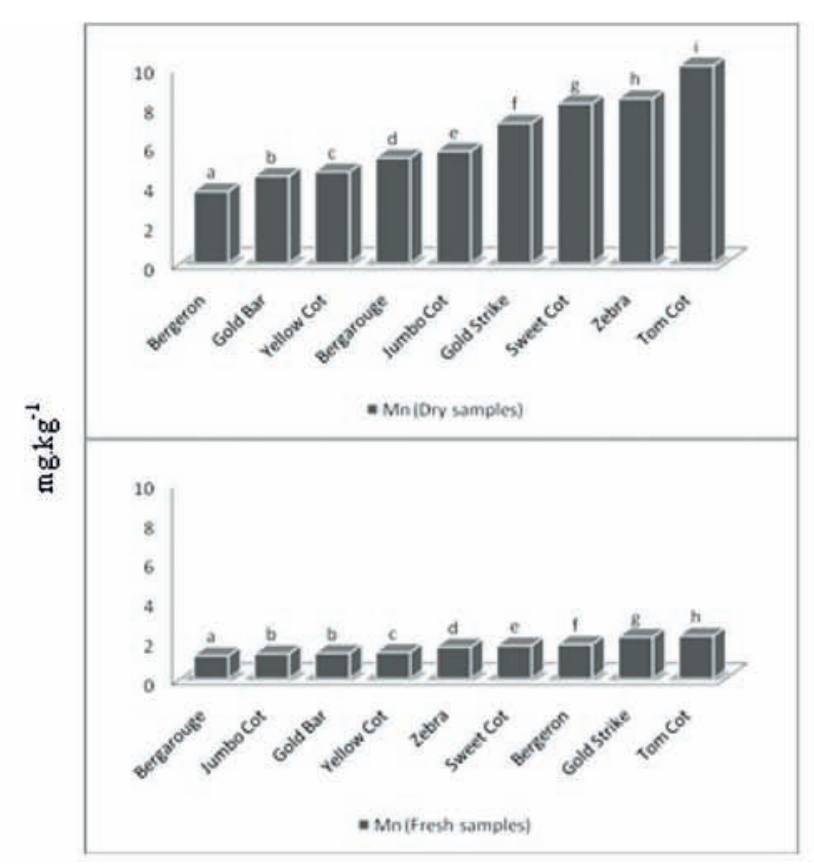

Figure 5. Concentration of Manganese in apricot cultivars (mg.kg-1), columns with different caption have a significant difference $(\mathrm{P} \leq 1 \%)$.

respectively (Sahan et al., 2007). Zahoor et al. (2003) counted $443.3 \mathrm{mg} \cdot \mathrm{kg}^{-1}$ of $\mathrm{Mg}$ in plum, $305.9 \mathrm{mg} \cdot \mathrm{kg}^{-1}$ in apricot, $275.3 \mathrm{mg} \cdot \mathrm{kg}^{-1}$ in peach, $260.8 \mathrm{mg} \cdot \mathrm{kg}^{-1}$ in pear and $211.4 \mathrm{mg} \cdot \mathrm{kg}^{-1}$ in apple which was lower than the highest concentration of $\mathrm{Mg}\left(638.63 \mathrm{mg} \cdot \mathrm{kg}^{-1}\right)$ in dried samples of "Goldstrike" cultivar. Consumption of each $100 \mathrm{~g}$ of this cultivar could supplement $63.8 \mathrm{mg}$ of human daily magnesium needed. This proves that apricot can play an important role in human diet as a safe source of $\mathrm{Mg}$.

\section{Manganese}

Manganese, like zinc and copper, is essential for normal prenatal and neonatal development. It is essential for human beings and animals. It plays an important role in bone mineralization, protein and energy metabolism, metabolic regulation, cellular protection from damaging free radical species, and the formation of glycosaminoglycans (Yang and Klimis-Tavantzis, 1998). Tuzen and Soylak (2007) recommended a 2-9 mg daily intake of Mn for adults. High-tech farming and lime added to soil can lower the manganese levels of certain foods. Manganese concentration in dried samples of this study range from $3.62 \mathrm{mg} / \mathrm{kg}$ in "Bergeron" to $10.11 \mathrm{mg} / \mathrm{kg}$ in "Tomcot" in comparison to $0.97-8.27$ mg.kg-1 of Turkish dried apricots (Saracoglu et al., 2009) and $0.037 \mathrm{mg} \cdot \mathrm{kg}^{-1}$ of Pakistan apricots in market (Zahir et al., 2009). In fresh samples, Manganese range between 1.13 mg.kg-1 in "Bergarouge" to 2.14 mg.kg- in "Zebra". In Fig. 5 the order of cultivars for Mn concentration and their differences are obvious. Duran et al. (2006) reported 8.2 $\mathrm{mg} . \mathrm{kg}^{-1} \mathrm{Mn}$ in apricots of Kayseri, Turkey which was lower than "Tomcot" in our study.

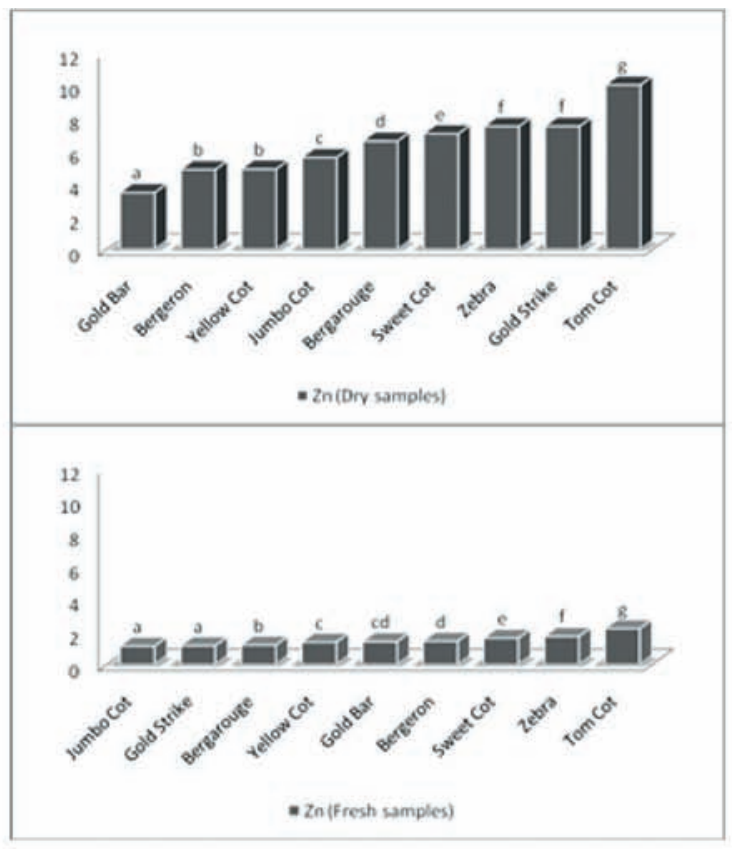

Figure 6. Concentration of Zinc in apricot cultivars (mg.kg-1), columns with different caption have a significant difference $(\mathrm{P} \leq 1 \%)$.

\section{Zinc}

Zinc is one of the most important trace metals for normal growth and development of humans. Deficiency of zinc can result from inadequate dietary intake, impaired absorption, excessive excretion or inherited defects in zinc metabolism (Tuzen and Soylak, 2007). General population exposure to zinc is primarily through ingestion. The average daily intake of zinc from food in human beings is $5.2-16.2 \mathrm{mg} \mathrm{Zinc} \mathrm{day}^{-1}$; assuming a $70 \mathrm{~kg}$ average body weight, this corresponds to $0.07-0.23 \mathrm{mg}$ zinc $/ \mathrm{kg} / \mathrm{day}$. Zinc is widespread in commonly consumed foods, but tends to be higher in those of animal origin, particularly some sea foods (Salgueiro et al., 2000; Beyersmann and Haase, 2001). The recommended dietary allowance (RDA) for zinc is 11 mgday $^{-1}$ for men and 8 mg.day ${ }^{-1}$ for women; these correspond to approximately 0.16 mg.kg ${ }^{-1}$.day ${ }^{-1}$ for men and $0.13 \mathrm{mgkg}^{-1}$ day $^{-1}$ for women (Stefanidou et al., 2006; Prasad and Kucuk, 2002). Zinc was in the range of $3.43 \mathrm{mgkg}^{-1}$ in "Goldbar" to $9.99 \mathrm{mgkg}^{-1}$ in "Tomcot" in dry samples in this study. The order of apricot cultivars for zinc concentration in dry samples is: Tomcot $>$ Gold stike $>$ Zebra $>$ Sweet cot $>$ Bergarouge $>$ Jumbo cot $>$ yellow cot $>$ Bergeron $>$ Gold bar. "Jumbocot" had the minimum concentration of Zinc and "Zebra" had the maximum of its concentration for fresh samples. Fig. 6 shows the differences between cultivars at $\mathrm{P} \leq 1 \%$.

Concentration of Zinc in examined cultivars were in the range of studied cultivars by [21] and was higher than what Zahir et al. (2009) reported from Pakistan. Leterme et al. (2006) counted Zinc concentration of fleshy tropical fruits of Colombia at a range of 0.9 (in pineapple) to $24.7 \mathrm{mgkg}^{-1}$ (in borojoa). Reports of greater amount of Zinc in apricot in our 
study and literature in comparison to some fruits like pineapple $\left(0.9 \mathrm{mgkg}^{-1}\right)$, orange $\left(2.2 \mathrm{mgkg}^{-1}\right)$, banana $(1.5$ $\left.\mathrm{mgkg}^{-1}\right)$, apple $\left(0.16 \mathrm{mgkg}^{-1}\right)$, guava $\left(2.00 \mathrm{mgkg}^{-1}\right)$ and mango $\left(1 \mathrm{mgkg}^{-1}\right)$ (Onianwa et al., 2001) make this evident that the consumption of apricot as a good source of zinc and other essential elements discussed above is a necessity.

\section{Conclusions}

The results represent that the apricot fruits had a metal content within the safe limits and none of the samples approached the PTDI for the trace metals studied except Se that had a higher concentration compared to the recommended daily intake but was in the range of tolerable upper intake. Based on our results in this article and low levels of hazardous elements in these 9 apricot cultivars [50], it could be concluded that these apricot cultivars are rich sources of different essential elements and their consumption in human dietary is beneficial to human health and can provide the necessary dose of elements needed by human body. Although, good quality control programs must be applied for the safety of consumers especially in processed fruits.

\section{Acknowledgement}

The research has been supported by National fund of Technological Development on the number TECH 08-A4/22008-0138 and TECH 08-A3/2-2008-0373.

\section{References}

Bahemuka, TE, Mubofu, EB (1999): Heavy metals in edible green vegetables grown along the sites of the Sinza and Msimbazi rivers in Dar es Salaam, Tanzania. Food Chemistry. 66 (1): 63-66.

Beyersmann, D, Haase, H (2001): Functions of zinc in signaling, proliferation and differentiation of mammalian cells. BioMetals. 14 (3): 331-341.

Dahmani-Muller, H, van Oort, F, Gélie, B, Balabane, M (2000): Strategies of heavy metal uptake by three plant species growing near a metal smelter. Environmental Pollution. 109 (2): 231-238.

Duran, A, Tuzen, M, Soylak, M (2008): Trace element levels in some dried fruit samples from Turkey. International Journal of Food Sciences and Nutrition. 59 (7-8): 581-589.

Ferreira, KS, Gomes, JC, Chaves, JBP (2005): Copper content of commonly consumed food in Brazil. Food Chemistry. 92 (1): 29-32.

Ford, ES (2000): Serum copper concentration and coronary heart disease among US adults. American Journal of Epidemiology. 151 (12): 1182-1188.

Gebeloglu, N, Camcicetin, S, Ece, A., Hayati, S., Mendil, D, Tuzen, M (2004): Determination of Trace Metals in Soil, Bean and Tomato Samples Collected from Agricultural Areas Near the Motorway in Tokat, Turkey. Asian Journal of Chemistry. 16 (3):1500-1504.
Gowrishankar, R, Kumar, M, Menon, V, Divi, SM, Saravanan, M, Magudapathy, P, Panigrahi, BK, Nair, KGM, Venkataramaniah, K (2010): Trace Element Studies on Tinospora cordifolia (Menispermaceae), Ocimum sanctum (Lamiaceae), Moringa oleifera (Moringaceae), and Phyllanthus niruri (Euphorbiaceae) Using PIXE. Biol Trace Elem Res. 133 (3): 357-363.

Guo, Y, Marschner, H (1995): Uptake, distribution, and binding of cadmium and nickel in different plant species. Journal of Plant Nutrition. 18 (12): 2691-2706.

Hedera, P, Fink, JK, Bockenstedt, PL, Brewer, GJ (2003): Myelopolyneuropathy and pancytopenia due to copper deficiency and high zinc levels of unknown origin - Further support for existence of a new zinc overload syndrome. Arch Neurol. 60 (9): 1303-1306.

Kabata-Pendias, A, Pendias, H (2000): Trace elements in soils and plants, $3^{\text {rd }}$ ed. Trace elements in soils and plants. CRC Press., Boca Raton

Leterme, P, Buldgen, A, Estrada, F, Londono, AM (2006): Mineral content of tropical fruits and unconventional foods of the Andes and the rain forest of Colombia. Food Chemistry. 95: 644-652.

Mansoor, MA, Bergmark, C, Haswell, SJ, Savage, IF, Evans, PH, Berge, RK, Svardal, AM, Kristensen, O (2000): Correlation between plasma total homocysteine and copper in patients with peripheral vascular disease. Clinical Chemistry. 46 (3): 385-391.

Munzuroglu, O, Karatas, F, Geckil, H (2003): The vitamin and selenium contents of apricot fruit of different varieties cultivated in different geographical regions. Food Chem. 83 (2): 205-212.

Nielsen, F. H. (1997): Boron in human and animal nutrition. Plant and Soil. 193. (1): 199-208.

Nziguheba, G, Smolders, E (2008): Inputs of trace elements in agricultural soils via phosphate fertilizers in European countries. science of the total environment. 390. (1): 53-57.

Onianwa, PC, Adeyemo, AO, Idowu, OE, Ogabiela, EE (2001): Copper and zinc contents of Nigerian foods and estimates of the adult dietary intakes. Food Chemistry. 72 (1): 89-95.

Paunovic, SA (1985): Apricot culture and apricot science. Acta Horticulturae. 192: 23-34.

Petris, MJ (2004): The SLC31 (Ctr) copper transporter family. Pflugers Archiv-European Journal of Physiology. 447 (5): 752-755.

Prasad, AS, Kucuk, O (2002): Zinc in Cancer Prevention. Cancer and Metastasis Reviews. 21 (3): 291-295.

Reilly, C (2004): Iron. In: The Nutritional Trace Metals. Blackwell Publishing, Oxford, UK \& Ames, Iowa. 35-81.

Sahan, Y, Basoglu, F, Gücer, S (2007): ICP-MS analysis of a series of metals (Namely: $\mathrm{Mg}, \mathrm{Cr}, \mathrm{Co}, \mathrm{Ni}, \mathrm{Fe}, \mathrm{Cu}, \mathrm{Zn}, \mathrm{Sn}, \mathrm{Cd}$ and $\mathrm{Pb}$ ) in black and green olive samples from Bursa, Turkey. Food Chemistry.105 (1): 395-399.

Ford ES, Mokdad AH (2003): Dietary Magnesium Intake in a National Sample of U.S. Adults. The Journal of Nutrition. 133 (9): 2879-2882.

Salgueiro, MJ, Zubillaga, M, Lysionek, A, Sarabia, MI, Caro, R, De Paoli, T, Hage, $\mathbf{A}$, Weill, R, Boccio, J (2000): Zinc as an essential micronutrient: A review. Nutrition Research. 20 (5): 737-755.

Saracoglu, S, Tuzen, M, Soylak, M (2009): Evaluation of trace element contents of dried apricot samples from Turkey. Journal of Hazardous Materials. 167 (1-3): 647-652. 
Stefanidou M, Maravelias C, Dona A, Spiliopoulou C (2006): Zinc: a multipurpose trace element. Archives of Toxicology. 80 (1): $1-9$.

Tagawa, T, Kono, K, Dote, T, Usuda, K, Nishiura, H, Koizumi, C, Saito, M, Nakaya, H, Nagaie, H (2000): Pharmacokinetics and effects after intravenous administration of high-dose boron to rat. International Archives of Occupational and Environmental Health. 73 (9): S98-S100.

Tüzen, M (2003): Determination of heavy metals in soil, mushroom and plant samples by atomic absorption spectrometry. Microchemical Journal. 74 (3): 289-297.
Tuzen, M, Soylak, M (2007): Evaluation of trace element contents in canned foods marketed from Turkey. Food Chemistry. 102:1089-1095.

Zahir, E, Naqvi, II, Uddin, SM (2009): Market basket survey of selected metals in fruits from Karachi city (Pakistan). Journal of Basic \& Applied Sciences. 5 (2): 47-52.

Zahoor, A, Jaffar, M, Saqib, M (2003): Elemental distribution in summer fruits of Pakistan. Nutrition \& Food Science. 33 (5): 203-207.

Yang, P, Klimis-Tavantzis, D (1998): Effects of dietary manganese on arterial glycosaminoglycan metabolism in sprague-dawley rats. Biological Trace Element Research. 64 (1): 275-288. 